\title{
Innovation technologies in Green Roof systems
}

\author{
Svetlana Korol ${ }^{1}$, Natalia Shushunova ${ }^{2}$, Tatiana Shushunova ${ }^{3 *}$ \\ ${ }^{1}$ Kuban State Technological University, Moscowskaya street, 2, Krasnodar, 350072, Russia \\ ${ }^{2}$ Moscow State University of Civil Engineering, Yaroslavskoe shosse, 26, Moscow, 129337, Russia \\ ${ }^{3}$ Mendeleyev University of Chemical Technology of Russia, Institute of Economics and Management, \\ Miusskaya square, 9, Moscow, 125047, Russia
}

\begin{abstract}
This article analyses both traditional green roof structures and innovative modular green roof systems. Project design and construction of new buildings with smart green technologies is a main trend in the process of mitigation climate change, because in most European countries the construction sector consumes approximately one third of the total energy used. Despite a wide range of proposed initiatives in the construction sector measures mainly focused on energy-saving technologies, alternative energy resources and methods to bring multiple economic profit and great environment benefits.
\end{abstract}

\section{Introduction}

Nowadays smart solutions of green roofs are popular for their ecological, technical, economic benefits and esthetic qualities. In the conditions of the urban development, the green roofing infrastructures with landscaping environmental elements is gaining popularity. When designing and installing green operated roofs, it is necessary to take into account the provisions of national regulations and green roof Codes, international standards, that carried out in the green buildings, specific climatic zones of the construction region and other factors in local conditions.

Megacities are the centers of a variety of innovations that can contribute to reducing or mitigating emissions, adapting to climate change and the ability to recover. Human activities, such as burning fossil fuels, large-scale industrial construction, deforestation, land-use changes, led, inter alia, to the accumulation of greenhouse gases in the atmosphere, coupled with a decrease in the ability of oceans and vegetation to absorb them. This has reduced the Earth's natural ability to maintain the balance of the carbon cycle and is now directly leading to current global changes in mean temperatures.

Among the main advantages of green roof systems is the variety of benefits and multifunctionality. Operated green roofs perform ecological functions, which include improvement of air quality and temperature-humidity regime, reduction of noise impact, that help to relief the Heat Island Effect. In addition, green roofs are the well-being habitat for local flora and fauna. The architectural functions include the design of the aesthetic appearance of buildings, the use of roofing for recreational areas and parking spaces and

\footnotetext{
* Corresponding author: nshushun@gmail.com
} 
creation of additional space in a cramped construction. The economic benefits of using green coatings are reflected in the investment attractiveness of the construction site, saving energy in heating systems and extending the life of the waterproofing and underlying coatings.

\section{Green innovations in urban space}

Modular green roof system is a technically advanced design solution of roofing, as well as innovative technological solutions with multifunctional advantages and the ability to integrate de-vices that convert solar and wind energy - solar panels and micro wind turbines. Modular trays are equipped with drip irrigation systems to create a microclimate zone directly above the roof of green building. The research describes modern green roof system, that consists of green roof modular pots with a big variety of configurations and integrated energy-effective devices (Figure 1).

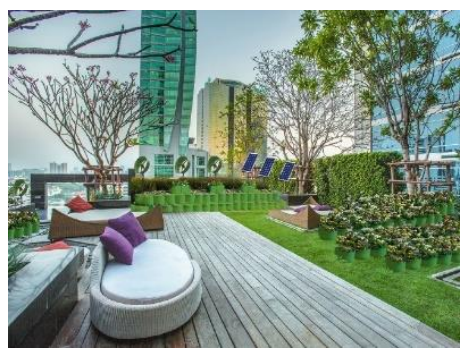

Fig. 1. Innovative green roof in urban space.

Nowadays technologies of construction of green roofing coverings acquire special importance. The big cities hold several environmental challenges: they occupy $3 \%$ of the land surface, host $50 \%$ of global population, consume $75 \%$ of natural resources, produce $50 \%$ of the global waste and emit $60-80 \%$ of greenhouse gases (GHG) [1]. Green roofs are both recreational zones and "elevators" for the development of the urban spaces. So, there is birth of the idea of turning a roofing cover into an exhibition and walking space with flowering gardens, combined with art objects using environmentally friendly materials. Such ergonomic solutions will be more effective in southern regions of countries with favorable climatic conditions. However, analysis of green technologies in different countries shows that the climatic features of the construction region do not play a key role in the choice of roofing. So, in Germany, on the terraces located on the southern slope from the end of the 18 th century to the pre-sent day, not only grapes, but also figs are grown, while in the winter spectacular plants are covered with glass frames. The task of modern builders and architects is to turn the city into a more natural and close to nature habitat. Green architecture, which implies energy efficiency, environmental friendliness of materials and reduced impact on the environment, will accelerate the movement to the urban development. The plants appear on walls, roof, terraces, floors of internal premises. To successfully development green technologies in many countries, it is necessary to take into account climatic conditions and develop national standards as BREEAM, DGNB or LEED rating systems of green buildings.

\subsection{Green roof benefits and improvements}

Widely there are great positions of the benefits and improvements of green roof system in urban space. Key benefits of green roof systems are following:

- Green roof installation provides energy savings. In London, a building services manager revealed that the application of a retrofitted green roof on a building had reduced the need for cooling/heating in the floor beneath. If the green roof had been installed as part of the 
original design of the building and the ability of the green roof to reduce cooling and heating requirements had been known, there would have been a big potential of energy efficiency of building. The urban scale extrapolation of the estimated energy savings with the dynamic energy simulations of the typical MF buildings shows that there can be green roofs in the city of Thessaloniki with reduced heating and cooling consumptions up to $5 \%$ and $16 \%$ respectively [2]. The energy savings both in heating and cooling are maximized underneath the green roof. Positive impact of green roof system on the energy performance of the buildings becomes more evident and noticeable. According to the dedicated measurements [3] of the selected rooftops of buildings, located in Guangzhou, China, the green roof systems reduce $15.2 \%$ cooling energy demand than the conventional roofs, had the better thermal performance and comfort.

- Mitigation of the urban heat island (UHI). The vegetative layer of the green roof reduces the harmful substances in the air due to the absorption of carbon dioxide $\mathrm{CO} 2$ and the release of oxygen. The green roof system neutralizes a significant amount of dust and harmful gases. The spirit on the green roof is much cleaner and contains $37 \%$ less $\mathrm{SO} 2$ (sulfur dioxide) and $21 \%$ less CO (carbon monoxide). The green roof addition-ally moistens the air, increase the longevity of the roof structure several times (3-4 times).

- Reduction of noise level up to 8-10 db. The soil is capable of absorbing the lower frequencies, and the vegetation is high, also the layer of soil cover is fireproofing, in case of fire, the soil layer will prevent its spread. According to some studies, approximately 20 million of adults, affecting daily activities, annoyed by environmental noise in urban areas [4]. Acoustic is cataloged as one of the major factors in the built environment quality.

- Versatile installation schemes and types of green roof system, improved method for roof covering. Protection of the roof membrane against extreme temperature fluctuations, UV radiation and physical damage from maintenance period, greened roof can double the material life.

- Lightweight, modularity and modern park-like design of green roof system with reversible inter-locking means, that easy and quickly to install, dismounting and maintenance.

- Effective water runoff management of green roof systems that provide water supply be special hydroponics system, including automatic watering system, pipes and ducts for water transfer (Figure 2).
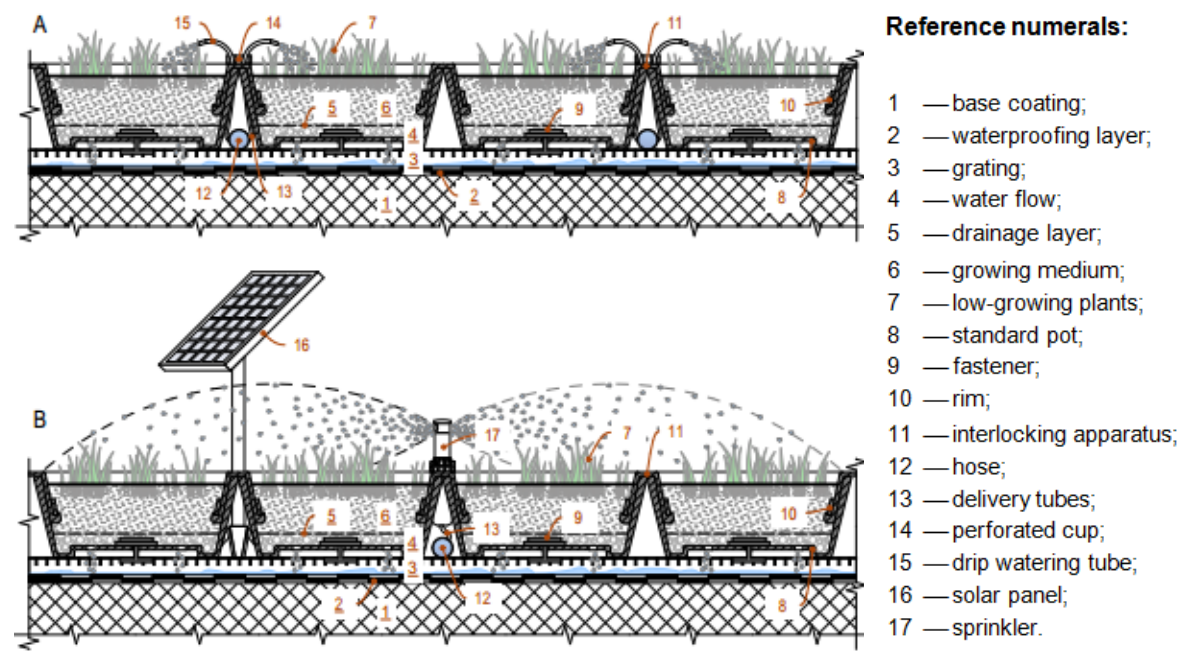

Fig. 2. Integrated solar panels and hydroponics of green roof system. 
- Plants diversity and multiplicity of modules comprises different configurations, sizes of diameters and heights that allows to use both intensive and extensive roof greening structures. The plants are selected according to the specific geographic zone and climate characteristics and green roof type such as extensive, semi-intensive and intensive roofs. And it shows interest in installation of this biggest variants of green roofs and their geographic applicability, which is available in many regions. It is important in selecting, that plants have fluence on the roof's performance and its tolerance to drought, wind, light, shade and pollutants. The low-growing plants may include a wider range of plant species such as Arenaria montana, Arenaria balearica, Arenaria sagina subulata "Aurea", collectively referred to as "Shortgrass Meadow Plantings". As another ex-ample, the vegetation could include another mixture of vegetation such as Sedum acre "Aureum", Sedum album "Coral Carpet", Sedum spatulifolium "Purpureum", Sedum spatulifolium "Cape Blanco", Sedum spurium "Green Mantle", Sedum spurium "Red Carpet", and Sedum kamtschaticum "Varie-gatum" (collectively referred to as "Desert Succu-lent Plantings"" Sedum spurium "Summer Glory", collectively referred to as "Desert Succulent Plantings" and others. According researching of scientists from Sydney succulent plants may be selected considering their drought resistance, low risk of fire, low cost and minimal ongoing maintenance [5]. Alternatively, the modular trays could be supplied without vegetation, for example, either empty, or with only the growth medium. Green roofs are popular in the rooftops of residential, public and commercial buildings, trade and office centers (Figure 3). Furthermore, system is able to install partially in the interior space as "landscaping" office to promote a healthy and well-being conditions.

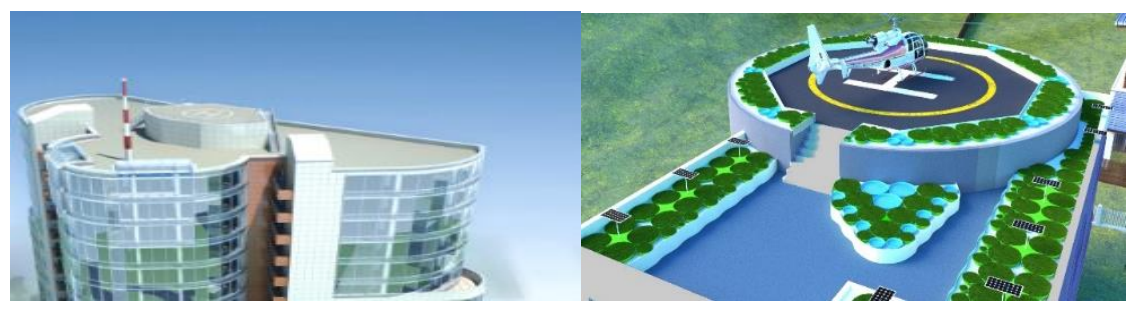

Fig. 3. Renovation project of modular green roof installation on trade-office center rooftop.

The present roofing system is to be solved various problems of roof covering by making inexpensive, little expenditure of labor and waste-free assembling based on the principle of building kit. The unique configuration of the system with an unusual combination of architectural and aesthetic design solutions gives a beautiful appearance to the urban areas and also allows to use methods of landscaping on living roof. The green roof technology includes the apparatus to integrate plurality of special roof covering elements with aspects of energy collecting and converting de-vices.

The essence of this innovation solution is in the fact that covering surface on the building roof is covered with special modular trays with vegetation, that fixed to the gratings by engagements. Modular trays are equipped with irrigation and drip irrigation systems to create a microclimate zone directly above the roof of the building. While the green roof covering modular device must be observe and control of the green roof installation process. The green roof installation process has the following steps:

- Correct and consistent installation process of the waterproofing layer and its compliance with the project specification. Proper installation of irrigation systems and drip irrigation, and matching their capacities and operating mode with the required parameters in accordance with the provisions of the Green roof standards, called also Green roof Code, that consist of special requirements for the device, and the rules of acceptance of control".

- Quality control of the roofing and grating mounting processes. According to the map have to be controlled. It should also be noted that the performance of work report of the roofing 
system installation must be carried out in the general journal papers or special journals of installation process on the forms, that considered in Russian requirements. To date the most widely accepted standard amongst the leading green roof suppliers is the German FLL standards, the landscaping and landscape Development Research Society. This standard is generally recognized as the benchmark for green roof installation quality. According to the German FLL standard a successful green roof system must basically replicate nature and consist of protection layer, drainage and filter layers, growing medium, appropriate components for vegetation and irrigation.

Big cities are adopting new building codes that incentivize adoption of innovative technologies in modern buildings. The green construction industry is moving fast, together with a growing trend for Green Building Rating Tools. The green roof systems, that installed on different types of buildings, can put you on the right track to earning the highest BREEAM, LEED, DGNB or HQE certification ratings. Building certifications such as LEED (Leadership in Energy \& Environmental Design) provide for certain tax credits of green roof using and benefits for building owners. There are several trends in development of friendly (green) technologies and production in construction in Russia [6], which needed for development in National building Codes. The survey of green roof module parameters shows that cooling electricity energy saving is around $12-15 \mathrm{kWh} / \mathrm{m} 2$ [7]. It pursues sustainable performance objectives while giving substantial importance to the life cycle analysis on a building scale and to the impacts of a project on health, comfort and the environment by using green roofs.

Following the same pattern, the Karlsruhe Performance Rating System rates green roofs according to natural categories. These functions, which assigned a weight based on its importance are as follows:

1. Type and depth of soil used (Soil) - 15\%;

2. Impact on climate due to evapotranspiration (Climate) $-15 \%$;

3. Type and variety of vegetation (Flora) $-30 \%$;

4. Impact on zoological biodiversity (Fauna) $-30 \%$;

5. Average annual stormwater retention (Water Balance) $-10 \%$.

The sum of the weighted rating for each of the five functions is used to compare different green roof systems and stipulate minimum requirements [8].

\subsection{Analyses of green roofing structures}

The device of green roof means the creation of structurally complex systems with vegetation and soil mixture placed on the waterproof membrane, with the integration of irrigation systems, as well as devices that convert solar and wind energy.

The green roof represents a multilayered structure and consists of several layers: a vegetative layer, a soil substrate, a filtering layer, a drainage system, a layer of waterproofing and a layer of thermal insulation. According to the standard TGRCS - Toronto Standard "Construction of green roofs", the green roof "pie" is shown as a multicomponent structure (Figure 4). 


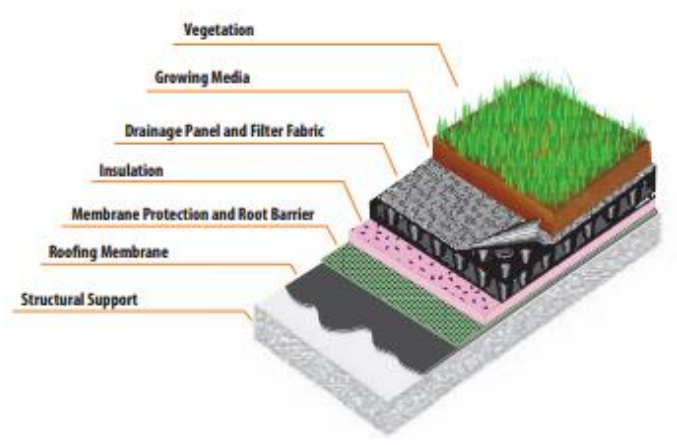

Fig. 4. The structure of the layers of the green roof «pie».

In this researching, each layer is examined for the analysis of the selection of the material of the roofing system and its features. The materials used for the construction of roofing surfaces must meet the requirements of the current standards in the field of standardization and green roofs types: intensive, semi- intensive and extensive roofs. For example, extensive green roof type (about $5-20 \mathrm{~cm}$ ) [9] comprised of several layers laid in sequence: root barrier, drainage layer, filter layer, growing medium and vegetation.

The vegetation is selected individually according to the climate conditions, the roof location and the thickness of the growing medium. Often, mosses, lawn grass, wildflowers and mountain vegetation are chosen for the green roof covering, since such vegetation is not whimsical to specific climate and regional conditions. The photosynthesis of green roof vegetation reduce the radiant, it also plays important roles in protecting the ecological environment and reducing dust and noise [10].

The growing medium is usually soil substrate or natural soil. Reduce the weight of the layer can effectively be due to the addition of loose fillers (peat, sand and unlimited additives). The soil depth is selected in accordance to the type of green roof: intensive or extensive types.

As a filter layer, a nonwoven material is used - geotextile. In this study, the analysis of the two most popular method of bonding-needle-piercing and thermal calendaring geotextile is given. According to the roofing technology, the thermally calendering geotextile is stronger for tearing than needle-punched. Thermally bonded geotextile, unlike needle-punched, has the property of high wear resistance and excellent tensile strength. The material is resistant to the effects of ultraviolet rays and aggressive medium, such as atmospheric moisture, acids, alkalis, bacteria or fungi.

The drainage removes excess water from the soil. In the drainage layer, polystyrene pellets are used. The most resistant materials for the anti-root layer are fiberglass, membranes made of synthetic material are also used. In case of green roof modules, the growing medium is separated from the drainage by a permeable geotextile fabric which is responsible for blocking soil penetrator.

The function of the waterproofing layer is to protect and prevent water and moisture from entering through the structure inside the building or onto external walls. As a waterproofing layer, a bituminous polymeric material should be used, laid in several layers:

- polymer waterproofing membranes on bitumen (EPDM) basis with anti-root protection, environmentally friendly material; or polymeric water-proofing membranes on a synthetic (PVC-membrane) basis with anti-root protection with life cycle up to 60 years;

- additional copper or aluminum foil layer to the membranes;

- liquid rubber;

- polyethylene film. 
If the roof is flat, then the waterproofing is arranged with a slope of $3 \ldots 5 \%$ to ensure the necessary flow of water. It is recommended to make a heat-insulating layer of foam glass or pearlite sand. Also as a heater apply extruded polystyrene plates and mineral wool. The thickness of the insulation of the coating is established by calculation, taking into account the heat-insulating properties of the remaining layers of the coating.

The study of thermal insulation of green roof systems in Hong Kong shown that use if green roof systems reduced the cooling load of the urban spaces and effectively decreased the indoor temperature [11].

The design of the intensive green roof differs from the extensive type. Insolation is located not on the bottom, but on the top of the waterproofing membrane, which protects it from mechanical damage. In this case, the required angle of inclination of the roof for the device of the green roof is $5 \ldots 8^{\circ}$. With an increase in the slope of the roof more than $12^{\circ}$, it is necessary to arrange transverse locks: wooden planks, geogrids or cassettes, which will hold back the soil. With the use of devices that prevent soil from slipping, planting of greenery on roofs with an angle of up to $45^{\circ}$ can be established. In modular green roof systems, the basic element is a tray, that quickly and easily mounted in a single covering. This system can be used on roofs with a slope of up to $20 \%$.

Many surveys show that intermittent ventilation is more conducive to indoor cooling and the green roof combined with intermittent ventilation is better [12]. The residents and landscape architects use the natural full time ventilation as one of main measures to improve the thermal performance of the building [13].

These recommendations are given for choosing the most energy-intensive and economical materials for structure of the of green roofing system. A detailed analysis of the multilayer structure of the green roof "pie" is presented the main features of using greening systems on roofing structures. The methodology for assessing the effectiveness is based on complex of developed energy-correcting measures in the organizational and technological design of construction projects $[14,15]$.

In study of $[16,17]$ it is noticed, that in Finland forests represent an iconic national landscape and novel green spaces meeting the needs and preferences of urbanites are considered increasingly important to produce livable urban environments.

\section{Conclusions}

Nowadays smart solutions of green roofs are becoming more and more popular in recent times for their ecological, technical, economic benefits and esthetic qualities. Successful urban planning including network of natural and semi-natural areas that integrate green roof systems into natural constructed urban environments. In the meantime, existing green roof technologies can be expensive to purchase and labor-intensive to install. This research is aimed to contribute to sustainable future-oriented solutions for the complex problems of urban areas to create livable ecosystems. Innovation technologies in green roof systems are an emerging trend in green building development. Innovative energy-efficient green technologies will bring a great benefit to the ecology and help to relief the Heat Island Effect, in light of growing concerns about climate change and greenhouse gas emissions (GHG). Innovative modular green roofs refer to rejuvenate and rebuild the nature. Although this study has made several advances in predicting benefits of green roof systems, and it has to move further on work pertaining to green roofs, there are several areas that will require further researching.

Modular green roof systems in urban space are becoming increasingly important part of the green building renaissance. Modular green roof constructive system is regarded to the most effective solution of innovative approaches and techniques for green design and construction. Trying to find the optimal system of green roof, this system is to be solved 
various problems of roof covering by making inexpensive, little expenditure of the labour and waste-free green roof assembling based on the principle of building kit. The unique configuration of the system with an unusual com-bination of architectural and aesthetic design solutions gives a beautiful appearance to the urban areas and also allows to use methods of land-scaping on living roof. This future-oriented green roof solution is appreciated by potential investors because implementing of this system can improve a company's competitiveness, bring multiple economic profit and great environment benefits.

\section{References}

1. Decision No 1386/2013/EU, Journal of the European Union L354, 171-200 (2013)

2. I. Theodoridou, M. Karteris, G. Mallinis, E. Tsiros, A. Karteris, Procedia Environmental Scienc-es 38, 530-537 (2017)

3. W.Yang, Sustainable Cities and Society 16, 1-12 (2015)

4. G.W. Evans, Environmental stress and health. Handbook of Health Psychology (Taylor \& Francis Group, New York, 2012)

5. S.Wilkinson, R. Castiglia Feitosa, I. Tsuyoshi Kaga, I. Hachmann de Franceschi, Procedia Engineering 180, 231 - 240 (2017) doi: 10.1016/j.proeng.2017.04.182

6. P.G. Grabovyi, L.A. Manukhina, Real Estate: Economics, Management 1-2, 6-8 (2014)

7. Zh. Tian, Y. Lei, X. Gu, Procedia Engineering 205, 2918-2924 (2017) doi: 10.1016/j.proeng.2017.10.095

8. S. Chowdhury, Y. Hamada, International Journal of Sustainable Built Environment, DOI : $10.101 /$ j.ijsbe.2017.09.001

9. D. Wang, N. Guan, Building Energy Efficiency 43(4), 57-60 (2015)

10. V.W. Tam, J. Wang, K.N. Le, Building and Environment 110, 46-54 (2016)

11. J. Ran, M. Tang, Energy Procedia 141, 260-266 (2017) DOI : 10.1016 /j.egypro. 2017.11.103

12. L. Fang, M. Xiaowen, Building Energy Efficiency 1, 108-113 (2015)

13. O.A. Korol, Journal of Scientific Review 12, 327-329 (2015)

14. M. Mesimäki, K. Haurub, D.J. Kotze, S. Lehvävirta, Land Use Policy 61, 587-600 (2017) DOI :10.1016/j.landusepol.2016.11.021 